Terry V. Callaghan ${ }^{1}$, Andrei A. Velichko ${ }^{2^{*}}$, Olga K. Borisova ${ }^{3}$

${ }^{1}$ Sheffield Centre for Arctic Ecology, Univ. Sheffield, UK; Abisko Research Station, Sweden; e-mail: t.v.callaghan@sheffield.ac.uk

$2^{2 *}$ Institute of Geography RAS, Moscow; e-mail: paleo_igras@mail.ru

(Corresponding author)

${ }^{3}$ Institute of Geography RAS, Moscow; e-mail: olgakborisova@gmail.com

\title{
TUNDRA IN A CHANGING CLIMATE
}

\begin{abstract}
Both palaeogeographical reconstructions and general circulation models indicate that global warming is especially strongly manifested in high latitudes. Under a $2^{\circ} \mathrm{C}$ increase in mean global temperature, almost the entire modern tundra zone would become potentially suitable for tree growth. Nevertheless, palaeobotanic data cannot be applied directly to estimating vegetation response to the global warming expected in the 21st century, as they characterize a quasi-equilibrium state of ecosystems, which takes several centuries to be achieved. Low migration rates of trees, damage caused by fires and insects, processes of soil drying or paludification, and influence of herbivorous animals and human activities may slow down considerably forest spread in tundra. Climate warming will probably cause a decline in the populations of Arctic species and expansion of ranges of some southern animal species into the Arctic.
\end{abstract}

KEY WORDS: tundra, polar ecosystems, global warming, northern tree line shifts

\section{INTRODUCTION}

In this article, the term "tundra" is used in its broadest sense to refer to the type of vegetation and ecosystems that occupy an area north of dense boreal forest. Clear boundary between these types of vegetation does not exist; they are linked by mutual gradual transition (ecotone) where, in the direction from south to north, closed northern forest gives way to sparse forest with patches of the tundra, then, to patches of forest in the tundra, and, finally, to the open tundra. Within the tundra/forest ecotone, «the northern border of the forest», i.e., the extent to which tree species penetrate to the north, can be traced. Currently, the northern forest tree line is between $51^{\circ} \mathrm{N}$ (in eastern Canada) and $84^{\circ} \mathrm{N}$ (in Greenland). In some regions, the tundra is only a narrow band of land (30-150 km) between the Arctic Ocean coast and the closed boreal forests. In these regions, the Arctic ecosystems are particularly vulnerable to expansion of woody vegetation under anthropogenic warming. Latitudinal patterns in the spread of the tundra are influenced by altitudinal zonation, therefore, in mountain areas of the south part of the forest/tundra ecotone, there is a complete transition from the northern boreal forest at low elevations to the tundra and screes in the upper mountain zone.

Global warming, detected qualitatively initially, began in northern Siberia and northeastern North America in the 1960s. Since then, the permafrost temperature has risen by $2-4^{\circ} \mathrm{C}$ in northwestern North America and by $0.6-0.7^{\circ} \mathrm{C}$ in Siberia [Anisimov et al., 2002] causing intensification of thermokarst processes and disturbances of soil cover. Under these conditions, the tundra transitioned from a carbon reservoir to a carbon source [Oechel et al., 1993]. Increased rate of decomposition of peat and growth of lake area caused a sharp increase in methane emissions [Zavarzin, Kudeyarov, 
2006; Christensen et al., 2004 and others]. Studies of possible changes in the tundra vegetation due to human-caused warming include the evaluation of the characteristic time lag of vegetation response to this warming and, in particular, the analysis of migration rates of tree species.

Although the current Arctic climate is warmer than at any other time in the last 400 years [Chapin et al., 2005], in the tundra, there are still some populations of plants, such as patches of sparse forest that are relics of even warmer Holocene Optimum conditions. Modern meridional gradients in the Arctic climate are significant. For example, the average July temperature and the annual precipitation range from 10 $12^{\circ} \mathrm{C}$ and $250 \mathrm{~mm}$ in the southern part of the tundra to $1.5^{\circ} \mathrm{C}$ and $45 \mathrm{~mm}$ in its far north, respectively [Callaghan et al., 2005]. The growing season determined by the temperature and duration of the snow cover, varies from 3.5 to 1.5 months. In the tundra zone, there is continuous permafrost with a 40-80 cm deep, on average, seasonally thawed layer increasing from north to south. Biological activity is mainly concentrated in the annual thawed layer; the nutrients are poorly available to plants because of the extremely slow decomposition of organic matter caused by various factors, including low soil temperature. The Arctic ecosystems have very low biological productivity. Nevertheless, the continued existence of an imbalance between the rates of carbon fixation and heterotrophic respiration led to a significant accumulation of carbon in the Arctic soils that contain about $12 \%$ of the global reserves of the soil carbon [McGuire et al., 2007].

Points of view of researchers on the classification of vegetation in the tundra and its geographic distribution are quite different. Assuming the broad definition of the tundra used herein, its total extent is about 7.5 million $\mathrm{km}^{2}$ [Bliss, Matveyeva, 1992]. Within the tundra, from south to north, in general, there is a reduction in plant height, storied structure, and vegetation productivity, and lesser participation of tree species in vegetation composition. However, as in any other zone, in the most favorable sheltered habitats, there may be an extrazonal community, for example, a plant population whose main range lies far to the south [Matveyeva, Chernov, 2000].

Biodiversity in the Arctic is rather low: it has about $3 \%$ and $2 \%$ of the global flora and fauna, respectively [Callaghan et al., 2005, Matveyeva, Chernov, 2000]. Nevertheless, some groups of plants (mosses, lichens, horsetails) in the tundra are very diverse. Other groups of species (e.g., large mammals) are very poorly represented here: after the extinction of the Pleistocene fauna at the end of the glacial epoch and the beginning of the Holocene, the tundra has been inhabited by only two species of large carnivores and 2 species of large herbivores [FAUNMAP Working Group, 1996]. In the tundra, there are over 1.800 species of vascular plants, 4000 species of spore-bearing plants, 75 species of terrestrial mammals, 240 species of birds, 3,200 species of insects, and 2.500 species of fungi [Callaghan et al., 2005, Matveyeva, Chernov, 2000]. Some species of animals and plants (e.g., reindeer, lemmings, cotton grass) are particularly numerous and widespread, and are typical of the Arctic. Trophic relationships in the tundra zone are relatively simple with short food chain. In the Arctic, about 3.8 million people reside, the native population comprising $8 \%$ [Chapin et al., 2005].

Plant and animal species, living in the Arctic now, have characteristics that, in the past, enabled them to overcome a variety of natural "filters" [Körner, 1995], whereas the more southern species did not pass this filter, or have not yet reached the Arctic in their distribution. In general, the adaptation of arctic plants and animals to the modern harsh climate led to their specific responses to warming and the invasion of more southerly species. The Arctic species are mostly longlived, slow growing, and have low and irregular reproduction rates [Callaghan et al., 2005]. 
This article is largely based on the analysis of material collected during the preparation of the section of Chapter 4 of the Report of the Working Group II IPCC in 2007, dedicated to the tundra ecosystems [Fischlin et al., 2007].

\section{RECENT AND ONGOING CHANGES IN THE FUNCTIONING OF SPECIES AND ECOSYSTEMS IN THE TUNDRA ZONE}

Basic conditions for the functioning of the arctic ecosystems (climate, ultraviolet radiation, degree of pollution, and socio-economic factors) are subject to constant changes [Callaghan et al., 2005, Chapin et al., 2005]. Below, we shall mainly focus on transformations of ecosystems in the tundra zone under the influence of climate change that occurred in the past or is anticipated.

Observations indicate a gradual increase in the role of shrubs and trees in the tundra zone. Thus, repeated aerial photography showed that the role of shrubs in tundra vegetation in northern Alaska has increased at 140 out of 200 sample plots [Sturm et al., 2001]. This trend is confirmed by satellite images analysis for a larger territory. Birch forests in a region of northern Norway have increased from $2.400 \mathrm{~km}^{2}$ in 1961 to over $3.500 \mathrm{~km}^{2}$ in 2000, and woody biomass increased by more than 60\% [Callaghan et al., 2005]. More subtle variations of the same trend were registered in other parts of Norway. It is likely that the increase in the role of birch forests was due to warming, as well as to other factors, such as changes in reindeer grazing patterns and restoration of birch forests after the damage caused by pests. Throughout Alaska, the border of the spruce range is gradually shifting to the north [Hinzman et al., 2005]. The area affected by this process is small in general, but as a result, over the last 50 years, the forest boundary shifted $10 \mathrm{~km}$ to the north and, on the Seward Peninsula, forests moved into about $2 \%$ of the tundra area. [Lloyd, 2005]. In the north of Sweden, the upper forest limit in the mountains, over the past 100 years, has moved up 40-70 m. This shift was occurring at a rate of about $0.5 \mathrm{~m} / \mathrm{yr}$, averaging about $40 \mathrm{~m}$ for $1^{\circ}$ temperature increase [Callaghan et al., 2005]. It was primarily due to warming of the mid-20th century and to some changes in land use.

At the same time, in some regions of northern Eurasia, the forest boundary moved south due to progressive paludification [Crawford et al., 2003; Hinzman et al., 2005]. At the same time, within the area from Archangelsk to Chukotka, tundra-like landscapes emerged in the area of about $470 \mathrm{~km}^{2}$ because of human disturbance, i.e., logging and foresttundra scorching [Vlassova, 2002]. Thus, in the Arkhangelsk region and Komi Republic, the tundra border zone is now $40-100 \mathrm{~km}$ further to the south than shown by earlier mapping. Numerous factors controlling the location of the northern forest boundary include winter snowiness, because, among other factors, the snow cover protects the young shoots of trees from being eaten by moose and reindeer [Cairns, Moen, 2004]. In cases where the forest boundary shifted to the north in response to the current global warming, such shifts should be considered in the context of the processes that developed throughout the Holocene, because in many locations, the modern forest boundary is in more southerly position than in the Holocene Climatic Optimum.

Vegetation in northern Finland and Norway experienced significant changes over the past 40 years: the area of plant associations with such dominants, as Vaccinium myrtillus, Deschampsiaflexuosa, and Cornus suecica and mosses increased there three-fold, whereas the area of lichen-ericoid communities and woodlands decreased by 80\% [Callaghan et al., 2005]. While it is likely that the reduction in the lichen communities was due to the intensification of reindeer grazing, other changes in vegetation were, apparently, the result of changes in climate (increased precipitation) and in the activity of insects.

According to experimental studies carried out during 8 years on the test sites in Alaska that included changes in the amount of snow and additional heating in summer, 
vegetation in the tundra responds more to an increase in summer precipitation than to temperature rise [Walker et al., 2006]. As the result, the canopy density and height of the shrub layer, along with the biomass of living plants and litter, increase. In wet soils, the role of mosses reduces, while the role of grasses and sedges grows. In the Point Barrow (Alaska) region, vegetation monitoring conducted in the last 30 years, have shown that vegetation of the moist and wet tundra is more susceptible to changes, while dry tundra communities are relatively stable and, in some places, are replacing communities of wet habitats [Hinzman et al., 2005]. These changes are associated with global warming, increasing depth of seasonal ground thawing, and its earlier onset. In addition, in some instances, drainage associated with human activities is of great importance.

In some regions in Alaska [Hinzman et al., 2005] and in Siberia [Smith et al., 2005], especially in the area of discontinuous, insular, and sporadic permafrost, in the past 30 years, there was the drying up of lakes with associated changes in the composition of plant communities. By contrast, in wetlands of the subarctic part of Sweden, the role of drier plant communities was declining, while the role of associations of wetland and aquatic habitats was increasing. These changes were caused by the degradation of discontinuous permafrost [Christensen et al., 2004].

Currently, 21 species of the Arctic mammals are threatened [CAFF, 2001]. However, modern trends may vary for different animal species and for different populations of one species [Callaghan et al., 2005, Chapin et al., 2005, CAFF, 2001]. While some populations of arctic species, such as arctic fox, are decreasing (possiblydueto changing weather conditions), some of the more southern species (fox, moose) are penetrating into the Arctic [Chapin et al., 2005]. Observations indicate an occasional appearance, among tundra species, of birds and insects not previously encountered in the Arctic.
Although the number of caribou in North America, as a whole, has increased due to the shift of the beginning of the growing season to an earlier date, the northern population of Peary caribou has declined, probably because of frequent adverse weather events (such as fall ice storms), and it is threatened with extinction. The population of domesticated reindeer in northern Russia has decreased by about 1 million animals over the past 10 years, but mainly for socioeconomic reasons [Callaghan et al., 2005]. Many species of Arctic animals have sharp fluctuations in numbers, some of which are cyclical in nature. In the past, a typical cycle of the number of lemmings in Alaska has become less expressive [Batzli et al., 1980]. Similar changes were also observed in Fennoscandia due to the fact that the state of the snow cover was less favorable for a winter food supply of lemmings and for nesting in the sub-nival cavities [Callaghan et al., 2005].

Every year, hundreds of millions of birds migrate to the Arctic. In recent times, many bird populations have decreased [Callaghan et al., 2005, Chapin et al., 2005, CAFF, 2001]; 12 species of arctic birds are threatened with extinction [CAFF, 2001]. While warming contributed to the penetration of some species of migratory birds farther north [Chapin et al., 2005], it is difficult to explain the declining populations of other species by climatic conditions.

The northern limits of distribution of Arctic species of insects are usually determined by climatic factors [Strathdee, Bale, 1998]. Distribution of some groups, for example, of Lepidoptera, is closely linked to climate variability, while others respond to these fluctuations with changes in their life cycle. These insects particularly easily adapt to climate change. Some of them are pests of forest tree species. In this regard, the establishment of warmer summer conditions caused sudden outbreaks of such pests as the spruce bark beetle and the spruce budworm, while winter warming have led to dramatic increase in autumn moth population, which 
causes significant damage to tree species in some regions of Alaska, Canada, Russia, and Fennoscandia [Juday et al., 2005].

Analysis of satellite images shows that the Arctic's greenness index (Normalized Difference Vegetation Index - NDVI) increased overall [Nemani et al., 2003] and the initiation of the growing season, in 1988-2001, has advanced by 8 days [Callaghan et al., 2005]. Net phytomass production (NPP) in some regions of North America and western Eurasia, has increased as well [Nemani et al., 2003, Sitch et al., 2007]. However, there are significant regional differences in the distribution of the abovementioned parameters. For example, since 1981, NDVI in Alaska has increased by 15\% [Myneni et al., 1997] with the increase of the length of the growing season by an average of 3 days per decade [McGuire et al., 2007]. At the same time, in Fennoscandia, NDVI increased significantly less and the duration of the growing season, in northern Eurasia, increased by only 1 day per decade. On the Kola Peninsula, the onset of spring was delayed, apparently due to increased snow cover and the recent cooling [Høgda et al., 2001]. Although, according to modeling results, a $1^{\circ} \mathrm{C}$ temperature rise should cause the birch buds to burst 3-8 days earlier, 70 year phenological observations in the mountains of Scandinavia showed no significant shift of this process to an earlier date in spite of the 20th century warming [Callaghan et al., 2005].

In the terrestrial Arctic ecosystems, a substantial part of global circulation of greenhouse gases occurs [Chapin et al., 2005]. Modeling studies [Callaghan et al., 2005, McGuire et al., 2007, Sitch et al., 2007] indicate the predominance of a weak carbon sink in the Arctic tundra in general: $17 \pm 40$ $\mathrm{g} \mathrm{C} \mathrm{m}{ }^{-2} \mathrm{yr}^{-1}$. However, such measurements based on year-round field observations are few and their geographical distribution is uneven. As a result, the addition of new field measurement data can affect the total assessment of the role of the circumpolar Arctic tundra as a source or sink of carbon.
Long-term (30 yrs) measurements of the carbon budget in Alaska showed a switch from carbon sink to source associated with warming and drying of the tundra habitat [Oechel et al., 1993]. Arctic wetlands are one of the major sources of methane to the atmosphere (about $70 \mathrm{Tg} / \mathrm{yr}$ ) [Cicerone R.J., Oremland and others]. Methane fluxes are highly variable in both space and time, which is associated with soil wetting and warming.

Arctic territories also impact the atmospheric temperature by reflecting solar radiation. The recent increase in the duration of the snow-free season and albedo decrease, due to increasing density of shrubs and woody vegetation penetration into the tundra, increased absorption of energy by about $3 \mathrm{~W} / \mathrm{m}^{2}$ per decade, which is close to the level of warming due to a doubling of $\mathrm{CO}_{2}$ in the atmosphere projected to occur over several decades [Chapin et al., 2005].

\section{EXPECTED CHANGES IN VEGETATION AND CLIMATE IN THE TUNDRA ZONE}

General circulation models and paleogeographic reconstructions show that global warming (current and projected for the 21 st century) is particularly pronounced at high latitudes, including the tundra zone. According to the estimates published by the Intergovernmental Panel on Climate Change (IPCC), in the 21st century, the temperature increase will be, most likely, within warming scenarios A1B and B1 [Climate Change, 2007]. Scenario A1B assumes that the rise in the average global temperature (AGT) will comprise $1.5^{\circ} \mathrm{C}$ by 2030 and $2.4^{\circ} \mathrm{C}$ by 2080 . According to scenario $\mathrm{B} 1$, the expected rise in temperature will be $0.8-1^{\circ} \mathrm{C}$ by 2030 and $1.9-2^{\circ} \mathrm{C}$ by 2080 . The average temperature rise estimated by IPCC will be $1.3^{\circ} \mathrm{C}$ by 2030 and $1.9-2^{\circ} \mathrm{C}$ by 2080 . The paleotemperature reconstruction of the Holocene Climatic Optimum (5.5-6 ka B.P.) conducted with palynological data and information-statistical method [Atlas of paleoclimates..., 1992] shows that the deviation from the modern AGT during that period was about $0.8-1^{\circ} \mathrm{C}$. 
In the last Interglacial Climatic Optimum (Eemian-Mikulino-Sangamon; about 125 ka B.P.), in the Northern Hemisphere, the deviation of $A G T$ from the present-day temperature reached $1.8-2^{\circ} \mathrm{C}$ [Velichko et al., 2002]. The reconstruction of the geographical distribution of the main climatic indexes from the modern values was conducted for these two levels of global warming [Atlas of paleoclimates..., 1992]. To evaluate the response of tundra vegetation to climate warming, it is particularly important to reconstruct summer temperatures, since the position of the northern border of closed northern forests corresponds roughly to the mean July isotherm of $12^{\circ} \mathrm{C}$ [Callaghan et al., 2005].

According to scenario A1B which assumes greater increase in temperature compared with scenario B1, summer temperatures in the high latitudes of Eurasia and North America will be $3-3.5^{\circ} \mathrm{C}$ higher than the current level by 2080 [Climate Change, 2007]. With this warming, the July isotherm of $12^{\circ} \mathrm{C}$ will move close to the coast of the Arctic Ocean in the north of Eurasia and the northwestern North America. A somewhat smaller increase in summer temperatures is expected to occur in northeastern North America. For the last Interglacial Climatic Optimum, the reconstruction from palynological data showed less significant deviations of summer temperatures from the modern values in northeastern North America [Velichko et al., 2002, Atlas of paleoclimates..., 1992]. In the north of Eurasia and North America, the average July temperature, in this period, exceeded $12^{\circ} \mathrm{C}$, reaching $14^{\circ} \mathrm{C}$ in the Arctic regions of Siberia. For the $0.8-1^{\circ} \mathrm{C}$ level of global warming (Holocene Climatic Optimum), the reconstructions showed even lower average July temperature. Only near the northern coast of Scandinavia, the average July temperature reached $14^{\circ} \mathrm{C}$. In the extreme north of the East European Plain, the summer temperatures were close to $12^{\circ} \mathrm{C}$. In Siberia, north of $70^{\circ} \mathrm{N}$, the average July temperatures ranged from 10 to $6^{\circ} \mathrm{C}$. In the tundra of North America, the summer temperatures were generally below $12^{\circ} \mathrm{C}$, except for slightly warmer southern and eastern regions [Atlas of paleoclimates..., 1992].

Defining the boundaries of areas where, under a given level of global warming, the average July temperature will exceed $12^{\circ} \mathrm{C}$, allows one to define which regions will be suitable for distribution of forests. The paleoreconstruction shows that when the AGT increases by $\sim 2^{\circ} \mathrm{C}$, almost the entire modern tundra zone will be potentially suitable for tree growth. With global warming of $1^{\circ} \mathrm{C}$, in both North America and Eurasia, areas suitable for tree growth will be much more limited.

These estimates correspond to the spread of tundra vegetation during the warmer times of the past, reconstructed from paleobotanical data [Khotinsky, Klimanov, 2002, Atlas of paleoclimates..., 1992]. For example, during the phase of the last Interglacial Climatic Optimum, the tundra in mainland Europe disappeared almost entirely (Fig. 1). Small patches of tundra in the European sector remained only on the Arctic islands. Coastal areas in the northeast of Europe were occupied by coniferous and mixed forests, which now grow almost 1,000 $\mathrm{km}$ to the south. In West Siberia, the tundra and the forest tundra occupied the Yamal Peninsula and the islands that existed in the location of the Gydan Peninsula, then separated from the mainland as a result of the Boreal transgression. A large part of the modern Western Siberian tundra was occupied by coniferous forests, similar in composition to the middle-taiga modern forests. Currently, the northern boundary of this subzone in Western Siberia is almost $400 \mathrm{~km}$ to the south compared with the last Interglacial Optimum. In the northeast Siberia, for example, on the Yana-Indigirka lowland, the distribution of the shrub-tundra and the forest-tundra was much closer to the present. The moss- and shrub-tundra remained only in the north of the Taimyr and on the Arctic Islands. In North America, in the last phase of the Interglacial Climatic Optimum, the tundra was present on the 
islands of the Canadian archipelago [Atlas of paleoclimates..., 1992].

In the Holocene Climatic Optimum, when global warming did not exceed $1^{\circ} \mathrm{C}$, the geographical range of the tundra was much wider than during the last Interglacial Optimum [Khotinsky, Klimanov, 2002]. Many regional studies and several international projects (e.g., Palaeovegetation Mapping Project (BIOME 6000) [Prentice et al., 1996], Palaeo-Arctic Treeline (PACT) Project [MacDonald et al., 2000], Circum-Arctic PalaeoEnvironments (CAPE) Project [CAPE Project Members, 2001], etc.) were devoted to the shifts of the northern forest boundary in response to the Holocene climate changes.

In the Holocene warming, the northern taiga replaced most of the tundra and the foresttundra at the high-latitude area of the East European Plain (see Fig. 1). In this region, the shift of the forest boundary to the north reached 200-250 km. In West and Central Siberia, the shrub tundra remained along the Arctic coast, although its width was at least 250-300 km less than its modern width due to the northerly expanse of the foresttundra. In North-East Asia, the spread of the tundra was close to the modern. In North America, the tundra/forest ecotone shifted significantly to the north in the Mackenzie River delta and on the Tuktoyaktuk Peninsula, but there remained a substantial asymmetry between the eastern and western sectors of the continent [Bigelow et al., 2003]. In Beringia, the location of the northern forest boundary was close to the present; in the Keewatin and Labrador areas, the ecotone's shift was $200 \mathrm{~km}$. About 6 ka B.P., on the Labrador Peninsula, there still remained a small residual glacier, which probably explains the anomalous position of the northern forest boundary in the Holocene Optimum in this region [Richard, 1995]. This border reached its most northern position later, after the complete collapse of the glacier [Richard, 1995]. The shrub tundra in the Holocene Optimum extended farther north than now, while the border between the northern and the southern belts of the dwarf shrub tundra was similar to the modern one [Bigelow et al., 2003].

Paleobotanical data allow one to assess the sensitivity of tundra vegetation to climatic fluctuations, but cannot be directly used to predict the response of plant communities to global warming expected in the $21 \mathrm{st}$ century, because they characterize the quasiequilibrium state of ecosystems [Velichko et al., 1991]. At least several centuries are needed to achieve such a balance, while the human-induced increase in $\mathrm{AGT}$ by $2^{\circ} \mathrm{C}$ may occur over several decades (by 2080). Largescale shifts in the boundaries of the tundra zone over the warm epochs of the past (see Fig. 1) corresponded to the final stages of a long gradual transformation of vegetation under the influence of warming [Velichko et al., 1991].

Most arboreal species require 15-30 years to reach fruitification. The range of seed dispersal is $1-2 \mathrm{~km}$ for pioneer tree species and several hundred meters for most forest tree species [Udra, 1988]. Under certain conditions, this range may increase. For example, the seeds of pine and spruce are carried sometimes by the wind on the frozen snow at a distance of $10 \mathrm{~km}$. The seeds of poplar and aspen can be moved during a storm for $30 \mathrm{~km}$ or more. Tree seeds can be carried by birds at large distances (on average 300-450 m), but startled birds can disperse seeds to 500-1000 m [Udra, 1988].

Changes in the composition and structure of tundra plant communities are also characterized by significant lags in relation to climate change that cause these changes [Callaghan et al., 2005, Chapin et al., 2000]. Under projected anthropogenic warming, the general direction and speed of transformation of tundravegetation is defined by many factors. The main factors are (1) the ecological amplitude of species-edificators of local zonal plant communities (e.g., whether newly formed climate conditions are within their tolerance), (2) the balance between the competitive power of the edificators of the zonal plant communities 

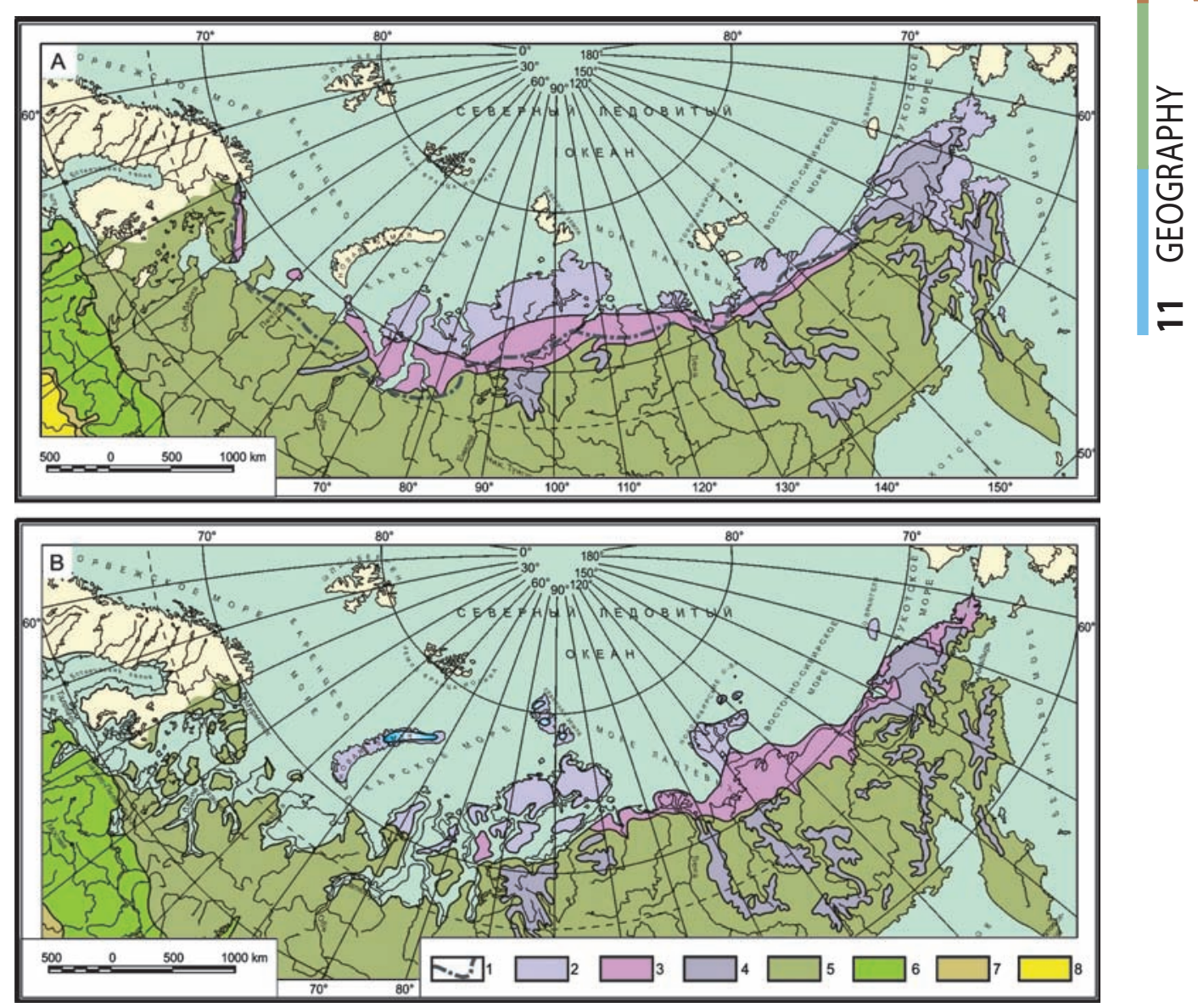

Fig. 1. The spread of the main vegetation types: $A-$ under $1^{\circ} \mathrm{C}$ global warming (Holocene optimum), after [Khotinsky, Klimanov, 2002]; B - under $2^{\circ} \mathrm{C}$ warming (the last interglacial optimum), after [Grichuk, 2002].

1 - modern tree line, 2 - Arctic, moss, dwarf shrub, and shrub tundra, 3 - forest-tundra, 4 - mountain tundra and shrub thickets, 5 - boreal forest, 6 - broad-leaved forest, 7 - forest-steppe, 8 -steppe

and of potential immigrants, and (3) the potential immigrants' location (how far from the border of the tundra these plants are found at the present and what is their characteristic migration rate) [Velichko et al., 2004]. Together, all these factors determine changes that occur in the structure and composition of vegetation under warming. When forest vegetation replaces the tundra, climatic conditions remain quite suitable for the existence of tundra vegetation, but it yields in the competitive power to the immigrants, i.e., to forest plants [Velichko et al., 1991, Callaghan et al., 2005].
The rates of migration of arboreal species may be assessed through studying their expansion under warming in the early Holocene. Thus, evaluation of the distribution rate of Larix was obtained from the radiocarbon dating of larch stumps found in situ in the Yenisei Siberia and on the Taimyr Peninsula [Nikolskaya, Cherkasova, 1982]. The distance from the modern boundary of larch to the most northern location of these findings on the shores of the lake Taimyr dated to $6,110 \pm 50 \mathrm{yr}$ B.P. (GIN-1005), was $200 \mathrm{~km}$. Thus, the migration rate of larch in this region in the early Holocene reached 
70-80 m/yr. It must be emphasized that these estimates relate to the migration rate of trees at the boundaries of their ranges. Palynological data for Western Europe (e.g., [Huntley, Birks, 1983]) suggest that the migration rate varied quite widely, both in time and space, and was of 200-300 m/yr on average, reaching 50-1000 m/yr for pioneer tree species. Similar estimates were obtained for North America [Davis, 1989]. Comparison of results of pollen analysis of Holocene peatlands located in the northern taiga zone of European Russia, with ${ }^{14} \mathrm{C}$ dates obtained from the macroremains of arboreal plants, suggests that the migration rate of trees in this region averaged $\sim 110 \mathrm{~m} / \mathrm{yr}$ [Velichko et al., 1991]. These figures are substantially higher than the current rate of dispersal characteristic for various species of trees. It was estimated [Udra, 1988] that the migration rate of pioneer species with light and easily dispersible seeds (birch, aspen) is $100-130 \mathrm{~m} / \mathrm{yr}$; this parameter for trees with heavier seeds is smaller, i.e., $10-25 \mathrm{~m} / \mathrm{yr}$, on average, for spruce and $30 \mathrm{~m} /$ year for pine. Apparently, these figures should be considered minimum estimates of the rates of propagation for these trees.

Thus, according to the paleogeographic data, in the near future, even with significant warming, there will be no significant shifts of the northern border of forest-forming species ranges. The migration of trees (and other plants) will be delayed inevitably with respect to climate change causing this shift. An important difference between the expected warming and the conditions of the distribution of forests in the early Holocene or the last Interglacial, is the rate of warming development, which, in most regions, is to exceed the natural rate of warming in the past. Another significant difference is the disturbance of the modern vegetation and animal population reduction because of human activities [Vlassova, 2002]. Under these conditions, the rate of migration of plants is likely to be lower than at the beginning of the Holocene. However, under the influence of changes in the length of the frost-free period, precipitation, and their within-year variability, significant changes in relative abundance of species that grow now in each specific territory can be expected.

During the warm periods of the past, the length of the frost-free period in northern Eurasia exceeded the modern by $30-40$ days. Annual rainfall, in the last Interglacial Optimum, in northern Siberia, was higher than the modern by the 50 $100 \mathrm{~mm}$; in the Arctic regions of North America, it was 25-50 mm higher [Atlas of paleoclimates..., 1992]. Almost 50\% of this increase of precipitation fell on the winter season, which should have lead to an increase in snow cover. Similar trends in the distribution of rainfall are expected in the future across the tundra, according to climate simulation (scenario A1B) [Climate Change, 2007]. Changes in the quantity and seasonal distribution of precipitation, not compensated by an increase in temperature, can cause a widespread waterlogging of soils and, therefore, may have a significant impact not only on tundra vegetation, but also on wildlife habitat in the tundra zone. In particular, an increase in snow cover and formation of crust of ice over snow during winter thaws make it difficult for reindeer to obtain food from beneath the snow [Callaghan et al., 2005].

Warming, as well as increased rainfall should have strong influence on a state of permafrost - an essential component of the tundra landscape [Anisimov et al., 2002]. In the tundra of northern Eurasia, in the northern part of continuous permafrost sub-zone, the temperature of the surface layer of permafrost over the last 20 years of the 20th centaury has increased by $0.5-$ $1^{\circ} \mathrm{C}$ [Anisimov et al., 2002]. The increase in soil temperature in the Arctic of North America has been even more significant. The projected increase in temperature of frozen soils under atmospheric general circulation models ESNAM1-A, GFDL89 and UKTR reaches $0.5-2^{\circ} \mathrm{C}$ with increasing thickness of the layer of the seasonal thawing by $30-50 \%$ in Alaska and Arctic Canada, by $15-20 \%$ in Western Siberia, and by $30-50 \%$ on the Chukotka Peninsula [Anisimov et al., 2002]. 
The simultaneous increase in temperature, in the thickness of the annual thawed layer, and in the moisture content in the upper layer of soils will not only boost the processes of waterlogging and thermokarst, but will have a significant impact on the ecosystems as a whole [Velichko et al., 2004]. Increasing instability of the layer of seasonal thawing will lead to intensification of the processes of mixing and lateral displacement of soil, which will cause a certain stress for plant root systems. These factors may also lead to slower processes of decomposition of plant litter and other organic debris. In the process of expansion of plants, such conditions are more favorable to wetland and hygrophilous species (e.g., Cyperaceae).

The changes described will inevitably affect the global carbon balance. The increase in the areas occupied by wetlands and waterlogged soils in the tundra may cause changes in the process of carbon sequestration and may slow down carbon emissions. Only in northern Russia, the carbon emissions from the tundra zone are $126 t^{6} / y r$. The expansion of forest vegetation in the tundra zone leads to increased carbon emissions from the soil. In the present conditions, the carbon emissions in the forest-tundra and the sparse boreal forests in northern Eurasia are twice the emissions from the open tundra, reaching $350 \mathrm{t}^{6} / \mathrm{yr}$ [Zavarzin, Kudeyarov, 2006]. Assessment of the balance between sequestration and emissions of carbon in the tundra zone under anthropogenic warming requires detailed specific studies.

Modeling the circumpolar vegetation distribution shows that under a doubling of $\mathrm{CO}_{2}$ in the atmosphere in different regions of the Arctic, the forest will replace the tundra on $11-50 \%$ of its current range [Callaghan et al., 2005, 32]. In those areas where the tundra forms, at the present, the narrowest strip, the forest will reach the coast of the Arctic Ocean. However, the degree of uncertainty of these models is very high [Callaghan et al., 2005]. The true rates of migration of tree species are likely to be significantly lower [Chapin et al., 2000]. The processes of drying, water logging [Crawford et al., 2003], and damage by fires and pests [Juday et al., 2005], and the impact of herbivores [Cairns, Moen, 2004] and humans [Vlassova, 2002] may significantly limit the spread of the forests in many regions. The forecast of changes in vegetation in the high Arctic shows that $17.6 \%$ on average (14 to $23 \%$ ) of the area occupied by the polar desert in 1960 will be covered with tundra vegetation by 2080 [Callaghan et al., 2005]. According to Biome4 model [Kaplan et al., 2003], the shrub tundra in Arctic Canada will remain as a wide zone replacing the dwarf-shrub-tundra. It must be emphasized that the models have limited ability to predict the distribution of vegetation that has no modern analogues (although the authors [Kaplan et al., 2003] have modeled the spread of Early-Holocene plant associations). Because of differences in the response of different plant species to climate change and the rate of their migration under the influence of warming, peculiar new kinds of plant communities will be formed.

Experiments with changes in the individual parameters of ecosystems show that, in general, the addition of nutrients causes the strongest feedbacks, whereas the response of plants to an increase of the heat supply is often limited by other factors, such as the availability of nutrients [Dormann, Woodin, 2002]. However, as has been observed in many parts of the Arctic, the summer temperature increase causes a reduction in the role of such important components of tundra vegetation as mosses and lichens, and promotes growth of vascular plants [Cornelissen et al., 2001]. In standardized experiments with additional heating conducted under the framework of the International Tundra Experiment (ITEX), a $1-3^{\circ} \mathrm{C}$ passive increase in temperature at the plants' height was achieved. Analysis of various parameters of the plant associations [Walker et al., 2006] showed rapid responses to this impact during two growing seasons. The height and cover of deciduous shrubs and graminoids increased; the cover of mosses and lichens decreased; and 
species diversity decreased. Such warming caused short-term decrease of biodiversity, but the duration of the experiments was not sufficient to allow for new species immigration and large-scale changes to occur such as transformation from tundra to forest. In general, the high Arctic tundra vegetation is less prone to changes than vegetation at the lower latitudes, where warming had the greatest effect on vegetation height. The results of the experiments that showed the increase of density and height of deciduous shrubs under warming are supported by natural observations that showed an increase in the role of the shrub vegetation in Alaska [Walker et al., 2006].

Evaluation of changes in the fauna of the tundra is even more difficult. Climate change will inevitably affect the distribution of biological productivity between different habitats, which is a potential source of variability in the number of vertebrates [Hinzman et al., 2005]. It is assumed that under the influence of warming, the number of arctic species will decrease. This reduction can be caused by a direct impact of weather conditions, such as the formation of ice crust in winter [Aanes et al., 2000], or indirect influence, for example, due to the disappearance of tundra wetlands that serve as habitat for migratory birds, as a result of drying [Hinzman et al., 2005, Smith et al., 2005], to invasion of shrubs, or to increase in vegetation height [Callaghan et al., 2005]. On the other hand, there may be northern expansion of animal species that live now in more southerly territories (moose, fox, etc.). Some of these animals achieve the character of "invasive" species making a negative impact on the key ecosystems and native species [FAUNMAP Working Group, 1996].

\section{CONCLUSION. \\ STABILITY OF ARCTIC ECOSYSTEMS IN THE WARMING WORLD}

Various aspects of Arctic ecosystems include climate stability, biodiversity, and resources of fuel, food, and vegetable fibers, as well as the cultural aspect [Chapin et al., 2005]. Climatic stability, as discussed above, will be likely determined by positive feedback that arises from the predominant influence of albedo changes because of diminishing snow cover and the expansion of areas occupied by arboreal vegetation, as well as due to an increase in methane emissions. In order to maintain biodiversity at the global level, it is very important to preserve groups of animals and plants that are widely represented in the Arctic, have astrong impact on Arctic ecosystems, or are threatened with extinction [Usher et al., 2005]. At the local level, the maintenance of biodiversity is necessary for the preservation of renewable resources for the local population. Changes in the availability of traditional resources may create additional difficulties for the aboriginal people, in addition to already existing stress caused by the globalization of the economy and lifestyle [Fischlin et al., 2007].

\section{REFERENCES}

1. Aanes, R., B.-E. Saether, N.A. Oritsland (2000) Fluctuations of an introduced population of Svalbard reindeer: the effects of density dependence and climatic variation // Ecography. V. 23. P. 437-443.

2. Anisimov, O.A., Velichko A.A., Demchenko P.F. et al. (2002) Effect of climate change on permafrost in the past, present, and future // Izv. Atmos. Ocean. Phys., V. 38, pp. 25-39.

3. Atlas of paleoclimates and paleoenvironments of Northern hemisphere. Late Pleistocene Holocene (1992) B. Frenzel, M. Pesci, A.A. Velichko (eds). Geogr. Res. Inst. HAS and Gustav Fischer Verlag, Budapest - Stuttgart,. 146 p. + maps. 
4. Batzli, G.O., R.G. White, S.F. MacLean, Jr., et al. (1980) The herbivore-based trophic system // An Arctic ecosystem: The coastal tundra at Barrow, Alaska. Stroudsburg: Dowden, Hutchinson and Ross. P. 81-95.

5. Bigelow, N.H., L.B. Brubaker, M.E. Edwards et al. (2003) Climate change and Arctic ecosystems: 1. Vegetation changes north of $55^{\circ} \mathrm{N}$ between the last glacial maximum, mid-Holocene, and present // J. of Geophys. Res. V. 108. № D19: 8170. doi:10.1029/2002JD002558.

6. Bliss, L.C., N.V. Matveyeva (1992) Circumpolar Arctic vegetation // Arctic and Alpine biodiversity patterns, causes and ecosystem consequences. Heidelberg: Springer. P. 59-89.

7. Cairns, D.M., J. Moen (2004) Herbivory influences tree lines // J. of Ecology V. 92. P. 1019-1024.

8. Callaghan, T.V., L.O. Bjorn, F.S. Chapin III et al. (2005) Arctic tundra and polar desert ecosystems // Arctic Climate Impact Assessment (ACIA): Scientific report. Cambridge: Cambridge Univ. Press. P. 243-352.

9. CAPE Project Members. (2001) Holocene paleoclimate data from the Arctic: Testing models of global climate change // Quat. Sci. Rev. V. 20. P. 1275-1287.

10. Chapin, F.S., A.D. McGuire, J. Randerson et al. (2000) Arctic and boreal ecosystems of western North America as components of the climate system // Global Change Biol. V. 6. P. 1-13.

11. Chapin, F.S., M. Sturm, M.C. Serreze et al. (2005) Role of land-surface changes in Arctic summer warming // Science. V. 310. P. 657-660.

12. Christensen, T.R., T. Johansson, N. Malmer et al. (2004) Thawing sub-arctic permafrost: Effects on vegetation and methane emissions // Geophys. Res. Lett. 31. 04501.

13. Cicerone, R.J., R.S. Oremland (1988) Biogeochemical aspects of atmospheric methane // Glob. Biogeochem. Cycles. V. 2. P. 299-327.

14. Climate Change. The Physical Science Basis. (2007) Contribution of Working Group I to the Fourth Assessment Report of IPCC. Cambridge: Cambridge Univ. Press. 996 pp.

15. Conservation of Arctic Flora and Fauna (CAFF). (2001) Arctic flora and fauna: status and conservation. Helsinki: Edita. 272 p.

16. Cornelissen, J.H.C., T.V.Callaghan, J.M. Alatalo et al. (2001) Global change and Arctic ecosystems: is lichen decline a function of increases in vascular plant biomass? // J. Ecology. V. 89. P. 984-994.

17. Crawford, R.M.M., C.E. Jeffree, W.G. Rees (2003) Paludification and forest retreat in northern oceanic environments // Ann. Botany. V. 91. P. 213-226.

18. Davis, M.B. (1989) Lags in vegetation response to greenhouse warming // Climatic Change. V. 15. P. $75-82$.

19. Dormann C.F., S.J. Woodin (2002) Climate change in the Arctic: Using plant functional types in a meta-analysis of field experiments // Functional Ecology. V. 16. № 1. P. 4-17. 
20. FAUNMAP Working Group. (1996) Spatial response of mammals to late Quaternary environmental fluctuations // Science. V. 272. P. 1601-1606.

21. Fischlin, A., G.F. Midgley, J.T. Price et al. (2007) Ecosystems, their properties, goods, and services // Climate Change 2007: Impacts, Adaptation and Vulnerability. Contribution of Working Group II to the Fourth Assessment Report of IPCC. Cambridge: Cambridge Univ. Press. P. 211-272.

22. Grichuk, V.P. Vegetation in the Late Pleistocene. In: A.A. Velichko (Ed.) Dynamics of landscape components and inner marine basins of Northern Eurasia over the last 130,000 years. GEOS, Moscow , pp. 64-89 (in Russian).

23. Hinzman, L.D., N.D. Bettez, W.R. Bolton et al. (2005) Evidence and implication of recent climate change in northern Alaska and other Arctic regions // Climatic Change. V. 72. P. 251-298.

24. Høgda, K.A., S.R. Karlsen, I. Solheim (2001) Climate change impact on growing season in Fennoscandia studied by a time series of NOAA AVHRR NDVI data // Geoscience and Remote Sensing Symposium, 2001. IGARSS '01, IEEE 2001.

25. Huntley, B., H.J.B. Birks (1983. An atlas of past and present pollen maps for Europe; 0-13 000 years ago. Cambridge: Cambridge Univ. Press.

26. Juday, G.P., V. Barber, P. Duffy et al. (2005) Forests, land management, and agriculture. Chapter 14 // Arctic climate impact assessment. New York: Cambridge Univ. Press. P. 781-862.

27. Kaplan, J.O., N.H. Bigelow, I.C. Prentice et al. (2003) Climate change and Arctic ecosystems: 2. Modeling, paleodata-model comparisons, and future projections // J. Geophys. Res. V. 108. № D19: 8171. doi: 10.1029/2002JD002559.

28. Khotinsky, N.A., V.A. Klimanov (2002) Holocene vegetation. In: A.A. Velichko (Ed.) Dynamics of landscape components and inner marine basins of Northern Eurasia over the last 130000 years. GEOS, Moscow, pp. 89-105 (in Russian).

29. Körner, C.H. (1995) Alpine plant diversity: A global survey and functional interpretations // Arctic and Alpine biodiversity patterns, causes and ecosystem consequences. Heidelberg: Springer. P. 45-62.

30. Lloyd, A.H. (2005) Ecological histories from Alaskan tree lines provide insight into future change // Ecology. V. 86. P. 1687-1695.

31. MacDonald, G.M., A.A. Velichko, C.V. Kremenetski et al. (2000) Holocene treeline history and climate change across Northern Eurasia // Quat. Res. V. 53. P. 302-311.

32. Matveyeva, N., Y. Chernov (2000) Biodiversity of terrestrial ecosystems // The Arctic environment, people, policy. Amsterdam: Harwood Acad. Publ. P. 233-274.

33. McGuire, A.D., F.S. Chapin III, C. Wirth et al. (2007) Responses of high latitude ecosystems to global change: Potential consequences for the climate system //Terrestrial ecosystems in a changing world. Berlin: Springer. P. 297-310.

34. Myneni, R.B., C.D. Keeling, C.J. Tucker et al. (1997) Increased plant growth in the northern high latitudes from 1981-1991 // Nature. V. 386. P. 698-702. 
35. Nemani, R.R., C.D. Keeling, H. Hashimoto et al. (2003) Climate-driven increases in global terrestrial net primary production from 1982 to 1999 // Science. V. 300. P. 1560-1563.

36. Nikolskaya, M.V., M.N. Cherkasova (1982) The dynamics of Holocene floras of Taimyr (based on paleophyitological and geochronological data). In: A.A. Velichko, I.I. Spasskaya, N.A.Khotinsky (Eds.) The development of the nature of the Soviet Union in the late Pleistocene and Holocene. Nauka, Moscow, pp. 192-201 (in Russian).

37. Nordengren, C., A. Hofgaard, J.P. Ball (2003) Availability and quality of herbivore winter browse in relation to tree height and snow depth // Annales Zoologici Fennici. V. 40. № 3. P. 305-314.

38. Oechel, W.C., S.J. Hastings, G. Vourlitis et al. (1993) Recent change of arctic tundra ecosystems from a net carbon sink to a source // Nature. V. 361. P. 520-523.

39. Prentice, I.C., J. Guiot, B. Huntley et al. (1996) Reconstructing biomes from palaeoecological data: A general method and its application to European pollen data at 0 and 6 ka // Climate Dynamics. V. 12. P. 185-194.

40. Richard, P.J.H. (1995) Le couvert végétal du Québec-Labrador il y a 6000 ans BP // Essai Geogr. Phys. Quat. V.49. P. 117-140.

41. Sitch, S., A.D. McGuire, J. Kimball et al. (2007) Assessing the carbon balance of circumpolar Arctic tundra with remote sensing and process-based modeling approaches // Ecological Appl. V. 17. P. 213-234.

42. Smith, L.C., Y. Sheng, G.M. MacDonald, L.D. Hinzman (2005) Disappearing Arctic lakes // Science. V. 308. P. 1429.

43. Strathdee, A.T., J.S. Bale (1998) Life on the edge: Insect ecology in Arctic environments // Ann. Rev. Entomol. V. 43. P. 85-106.

44. Sturm, M., C. Racine, K. Tape (2001) Climate change: increasing shrub abundance in the Arctic // Nature. V. 411. P. 546-547.

45. Udra, I.F. (1988) Expansion of plants issues and plant paleobiology. Naukova Dumka, Kiev, 163 p. (in Russian).

46. Usher, M.B., T.V. Callaghan, G. Gilchrist et al. (2005) Principles of conserving the Arctic's biodiversity // Arctic Climate Impact Assessment (ACIA): Scientific report. Cambridge: Cambridge Univ. Press. P. 539-596.

47. Velichko, A.A., O.K. Borisova, E.M. Zelikson (2002) Paradoxes of climate of the last interglacial period // Paths of Evolutionary Geography (results and prospects). Institute of Geography of the Russian Academy of Sciences, Moscow, pp. 207-239 (in Russian).

48. Velichko, A.A., O.K. Borisova, E.M. Zelikson (1991) Vegetation in a changing climate // Bulletin of the Academy of Sciences of the USSR, № 3, pp. 82-94 (in Russian).

49. Velichko, A.A., O.K. Borisova, E.M. Zelikson, T.D. Morozova (2004) Changes in vegetation and soils of the East European Plain to be expected in the 21st century due to the anthropogenic change in climate // Geographia Polonica. V. 77. № 2. P. 35-45. 
50. Vlassova, T.K. (2002) Human impacts on the tundra-taiga zone dynamics: The case of the Russian lesotundra // Ambio Spec. Rep. V. 12. P. 30-36.

51. Walker, M.D., C.H. Wahren, R.D. Hollister et al. (2006) Plant community responses to experimental warming across the tundra biome // P. Natl. Acad. Sci. USA. V. 103. P. 1342-1346.

52. Zavarzin, G.A., V.N. Kudeyarov (2006) Soil as a major source of carbon dioxide and organic carbon reservoir in Russia // Bulletin of the Academy of Sciences of the Russian Academy of Sciences, V. 76, № 1, pp. 14-29 (in Russian).

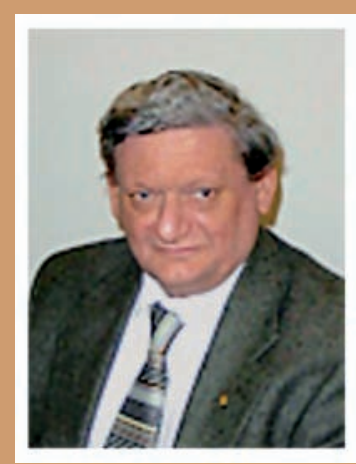

Terry V. Callaghan is Professor of Arctic Ecology and Director of Sheffield Centre for Arctic Ecology, University of Sheffield (UK) and Director of Abisko Scientific Research Station of the Royal Swedish Academy of Sciences. His research focuses on relationships between the arctic environment and the ecology of arctic plants and animals including ecosystem processes. The research has two components: seeking to understand mechanisms of survival and adaptation to arctic environments, and assessing the responses of organisms and ecosystems to changing environmental conditions such as climate, UV-B radiation and atmospheric $\mathrm{CO}_{2}$ concentrations.

In 2007 Professor T.V. Callaghan received the Nobel Peace Prize as a Lead Author of the Report of the Intergovernmental Panel on Climate Change (group award to the authors of IPCC, together with AI Gore).

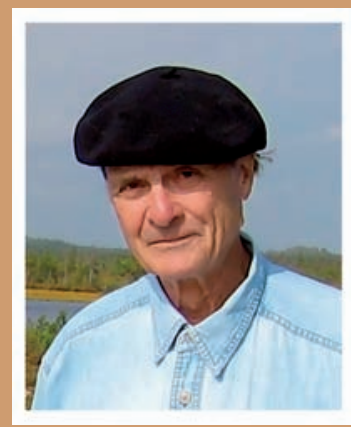

Andrei A. Velichko, Professor, is Head of Laboratory of Evolutionary Geography of the Institute of Geography, Russian Academy of Sciences. He is a well-known expert in physical geography, as well as climatic and environmental changes in the past and their possible projection into the future.

In 2007 Professor A.A. Velichko received Nobel Peace Prize as a Lead Author of the Report of the Intergovernmental Panel on Climate Change (group award to the authors of IPCC, together with Al Gore).

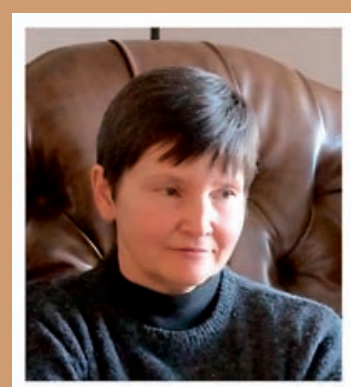

Olga K. Borisova is Leading Researcher at the Laboratory of Evolutionary Geography of the Institute of Geography, Russian Academy of Sciences. She is a specialist in pollen analysis of the Quaternary sediments. Her main interests are palaeoecological studies (landscape and climatic reconstructions based on the palaeobotanical data), inter-regional comparison of ecosystems and climatic changes in the past and estimation of possible future changes under the global warming. 